\title{
Chronic Inflammatory Rheumatic Diseases in Rheumatological Practice in Lomé (Togo)
}

\author{
Kodjo Kakpovi', Sadat Oniankitan², Komi C. Tagbor ${ }^{3}$, Koulouktsoa Kondian², \\ Viwalé ES Koffi-Tessio², Awaki-Esso Atake4, Lamine Mamadou Diallo3, Pahimi Yibe², \\ Erika Djougnwe Mba $^{3}$, Moubarak Tiadjeri³ , Eyram Fianyo3 ${ }^{3}$ Prénam Houzou${ }^{4}$, \\ Owonayo Oniankitan ${ }^{2}$, Moustafa Mijiyawa ${ }^{2}$
}

\author{
${ }^{1}$ Rheumatology Department, Regional Teaching Hospital of Kara, Kara, Togo \\ ${ }^{2}$ Rheumatology Department, University Teaching Hospital Sylvanus Olympio, Lomé, Togo \\ ${ }^{3}$ Rheumatology Department, Hospital of Be, Lomé, Togo \\ ${ }^{4}$ Rheumatology Department, University Teaching Hospital of Kara, Kara, Togo \\ Email: kakpovik@yahoo.fr, sadatoniankitan@gmail.com,tcyrille18@yahoo.ca, taffa.kondian@gmail.com, \\ anitess2005@gmail.com, awakiatake26@gmail.com, diallolaminemodric6842@gmail.com, florencepahimi@gmail.com, \\ mbaerikamba@gmail.com, tiadjerimoubarak@gmail.com, efianyo@gmail.com,h_prenam@yahoo.fr, owonayo@yahoo.com, \\ moustafa.mijiyawa@gouv.tg
}

How to cite this paper: Kakpovi, K., Oniankitan, S., Tagbor, K.C., Kondian, K., ES Koffi-Tessio, V., Atake, A.-E., Diallo, L.M., Yibe, P., Mba, E.D., Tiadjeri, M., Fianyo, E., Houzou, P., Oniankitan, O. and Mijiyawa, M. (2022) Chronic Inflammatory Rheumatic Diseases in Rheumatological Practice in Lomé (Togo). Open Journal of Rheumatology and Autoimmune Diseases, 12, 920 .

https://doi.org/10.4236/ojra.2022.121002

Received: October 1, 2021

Accepted: December 18, 2021

Published: December 21, 2021

Copyright (C) 2022 by author(s) and Scientific Research Publishing Inc. This work is licensed under the Creative Commons Attribution International License (CC BY 4.0).

http://creativecommons.org/licenses/by/4.0/ (c) (i) Open Access

\begin{abstract}
Chronic inflammatory rheumatism is a pathology of variable frequency and severity with a significant impact on the socio-economic, personal and family level. Study Aim: To describe the epidemiological, clinical, laboratory, radiological, therapeutic and evolutive features of chronic inflammatory rheumatic diseases in rheumatological practice in Togo. Patients and Methods: This was a multicenter cross-sectional study conducted from January 2011 to December 2019 on patients examined in the three rheumatology departments in Lomé (Togo). Patients 18 years old and above who have presented joint pain with or without synovitis, and/or rachialgia (back pain) for at least three months were included. The diagnosis of chronic inflammatory rheumatic diseases was made according to international consensus criteria. Results: Out of the 20333 patients whose files were collected during our study period, 290 (1.43\%) suffered from chronic inflammatory rheumatic diseases. There were 226 (77.93\%) females and $64(22.07 \%)$ males. The mean age of the patients was $42.79 \pm$ 15.18 years. The mean duration of symptoms was $40.80 \pm 54.09$ months. Arthritis (67.24\%) was the main reason for consultation, followed by joint pain (31.38\%). rheumatoid arthritis (41.03\%), unclassified chronic inflammatory rheumatic diseases (38.62\%), spondyloarthropathies (15.17\%) and systemic lupus erythematosus (2.41\%) were the major clinical forms. The immunological tests performed in $13.79 \%$ of cases were positive in $52.94 \%$ of cases. Carpitis (57.55\%) and diffuse osteoporosis (45.28\%) were the commonest radio-
\end{abstract}


graphic features of the hands. 289 patients (99.66\%) received symptomatic treatments such as NSAIDs (73.36\%) and corticosteroids (51.90\%) and 90 patients $(31.03 \%)$ were treated with synthetic DMARDs such as methotrexate $(88.89 \%)$. The outcome was favorable in $27.93 \%$ of cases. Conclusion: Chronic inflammatory rheumatic diseases are common diseases in rheumatological practice in Togo that deserve special attention. The establishment of a specialized immunology laboratory could be very useful for the diagnosis and early management of these diseases.

\section{Keywords}

Chronic Inflammatory Rheumatic Diseases, Rheumatoid Arthritis, Spondyloarthropathies, Sub-Saharan Africa

\section{Introduction}

Chronic inflammatory rheumatic diseases (CIRDs) are conditions that exhibit an autoimmune and/or autoinflammatory process as pathogenic mechanism. They constitute a public health issue in developed countries [1] [2]. In sub-Saharan Africa, few epidemiological studies have been devoted to them. Most studies were conducted in urban areas and were the result of hospital consultations [3] [4]. Very little information is available about these diseases due to the scarcity of studies conducted on them, which might also be associated to the poor coverage of the African continent in terms of physician specialists and well equipped rheumatology and immunology units [5] [6]. In Togo, most studies on CIRD were monocentric and focused either on CIRDs in general or on one particular CIRD [7] [8] [9] [10] [11]. The scarcity of epidemiological surveys explains the fragmentary nature of the data currently available. The aim of our work was to determine in a larger population of rheumatic patients, the distribution as well as the epidemiological, clinical, laboratory, radiological, therapeutic and evolutive features of the different CIRDs observed in the rheumatology units of Lomé.

\section{Patients and Methods}

This was a multicenter, cross-sectional study on patients' files, conducted from January 1, 2011 to December 31, 2019 in the rheumatology units of Lomé: $C H U$ Sylvanus Olympio (Sylvanus Olympio Teaching Hospital), CHR Lomé-Commune (Lomé-Commune Regional Hospital) and Hôpital de Bè (Bè Hospital). The study was approved by the ethics committee. Patients who have been suffering from inflammatory rheumatic diseases for more than three months were included in the study. Patients who were suffering from osteoarthritis, infectious arthritis, metabolic and endocrine arthropathies, and arthropathies related to hematologic diseases were not included in the study. The medium for collecting information was an individual information sheet with the following parameters studied: so- 
ciodemographic data (age, sex, occupation, place of residence, socioeconomic level), medical history, clinical data (reason for consultation, general signs, physical signs), laboratory and radiological data (erythrocyte sedimentation rate (ESR), full blood count (FBC), creatinine, hemoglobin electophoresis, Human Immunodeficiency Virus (HIV) serology, radiographs of painful joints and frontal lungs radiographs), diagnostic criteria (rheumatoid arthritis (ACR/EULAR 2010 criteria [12]); spondyloarthritis (modified New York criteria [13]), systemic lupus erythematosus (ACR 1982/1997 [14], systemic scleroderma (criteria of systemic sclerodermia [15]), polymyositis ( criteria of Hoogendijk [16]), Adult Still's disease (criteria of Fautrel [17]), Psoriasis arthritis (criteria of CASPAR 2006 [18]), Reactive arthritis (any episode of peripheral arthritis associated with an underlying infection (conjunctivitis, urethritis, cervicitis)); patients who did not meet these criteria were classified as having undifferentiated chronic inflammatory rheumatic diseases (UCIRD)), therapeutics used (corticosteroids, NSAIDs, analgesics, synthetic Disease Modifying Anti Rheumatic Drugs (DMARDs); no patient received biotherapy) and evolutive data (clinical course). Some patients underwent immunological testing: rheumatoid factor, anti-cyclic citrullinated peptide antibody (anti-CCP), screening and identification of antinuclear antibodies (ANA). HLA typing was not performed in any patient.

Fever was defined as body temperature above or equal to $38^{\circ}$ celsius. The patient's general appearance was described as ill when there was fatigue, anorexia, weight loss, and pallor, or at least two of these symptoms. Anaemia was defined as a hemoglobin level below $10 \mathrm{~g} / \mathrm{dl}$; leukocytosis was defined as a white blood cell count of more than 10,000 per $\mathrm{mm}^{3}$ on the $\mathrm{FBC}$, while leukopenia was defined as a white blood cell count below 4000 per $\mathrm{mm}^{3}$; thrombocytosis and thrombocytopenia were defined as a platelet count above 400,000 per $\mathrm{mm}^{3}$ and below 150,000 per $\mathrm{mm}^{3}$ respectively. The ESR was considered accelerated when above $20 \mathrm{~mm}$ at the first hour. C-reactive protein level was considered high for a value above $6 \mathrm{mg} / \mathrm{L}$. Anti-nuclear antibodies were considered high when the titer is above $160 \mathrm{IU} / \mathrm{ml}$. Rheumatoid factor, anti-cyclic citrullinated peptide (anti-CCP) antibodies and anti-Ro antibodies were considered positive when titer is above $10 \mathrm{IU} / \mathrm{ml}$. Anti-native DNA were positive when titer is above $15 \mathrm{IU} / \mathrm{ml}$. Anti-Jo1, anti-La and anti-Scl70 were considered positive when titer is above $7 \mathrm{IU} / \mathrm{ml}$. Anti-RNP was positive when titer is above or equal to $5 \mathrm{IU} / \mathrm{ml}$. Data analysis was performed using Epi Info software version 7.2.3.1.

\section{Results}

Out of the 20333 patient files collected during our study period, 290 patients suffered from CIRD, with an incidence of $1.43 \%$. They comprised 226 females (77.93\%) and 64 males (22.07\%) (Table 1). Their mean age at consultation was $42.79 \pm 15.18$ years. The mean duration of the symptoms before consultation was $40.80 \pm 54.09$ months. Sixty patients $(20.69 \%)$ had a personal medical history (high blood pressure (51.67\%), diabetes (25\%), ulcer (13.33\%), sickle cell 
Table 1. Socio-demographic data of patients with chronic inflammatory rheumatism.

\begin{tabular}{|c|c|c|}
\hline & Number of patients & Percentage \\
\hline \multicolumn{3}{|l|}{ Sex } \\
\hline Female & 226 & 77.93 \\
\hline Male & 64 & 22.07 \\
\hline \multicolumn{3}{|c|}{ Residential area } \\
\hline Urban & 238 & 82.07 \\
\hline Rural & 52 & 17.93 \\
\hline \multicolumn{3}{|c|}{ Niveau socio-économique } \\
\hline Low & 213 & 73.45 \\
\hline Medium & 72 & 24.83 \\
\hline High & 5 & 1.72 \\
\hline \multicolumn{3}{|c|}{ Statut matrimonial } \\
\hline Married & 177 & 61.03 \\
\hline Single & 72 & 24.83 \\
\hline Widower & 26 & 8.97 \\
\hline Divorced & 15 & 5.17 \\
\hline \multicolumn{3}{|l|}{ Occupation } \\
\hline Trader & 166 & 57.24 \\
\hline Civil servant & 57 & 19.66 \\
\hline Student & 36 & 12.42 \\
\hline Housewife & 22 & 7.59 \\
\hline Farmer & 9 & 3.1 \\
\hline
\end{tabular}

anemia (5\%), HIV infection (3.33\%), asthma (1.67\%) and five (1.72\%) had a family history of chronic inflammatory rheumatism. Arthritis (67.24\%) was the first reason for consultation, followed by joint pain (31.38\%) and large joints were the most affected in $60.49 \%$ (Table 2). Knees (59.31\%), wrists (54.48\%) and ankles $(49.31 \%)$ are the joints commonly affected. joint deformities were observed in $18.97 \%$ of cases with a clear predominance of patients suffering from rheumatoid arthritis (33.61\%). Ulnar finger cupping (40\%) and buttonhole fingers $(21.82 \%)$ were the most observed deformities (Figure 1$)$. The extra-articular features were mostly dermatological manifestations (52.83\%) and pulmonary involvement (28.30\%) (Table 3 ). The ESR was accelerated in $87.60 \%$ of cases and the C-reactive protein was elevated in $50.62 \%$ of cases. The immunological tests performed in $13.79 \%$ of cases were positive in $52.94 \%$ of cases. Rheumatoid factor performed by 31 patients $(77.50 \%)$ was positive in $54.84 \%$ of cases and Anti-citrullinated cyclic peptides, performed by 24 patients $(60 \%)$ were positive 
Table 2. Distribution of patients according to clinical features of chronic inflammatory rheumatic diseases (CIRD).

\begin{tabular}{|c|c|c|c|}
\hline & & Number & Percentage \\
\hline \multicolumn{4}{|c|}{ Reasons for consultation } \\
\hline- & Arthritis & 195 & 67.24 \\
\hline- & Joint pain & 91 & 31.38 \\
\hline- & Rachialgia & 34 & 11.72 \\
\hline- & Functional impotence & 11 & 3.79 \\
\hline \multicolumn{2}{|c|}{ Inflammatory pain timeline } & 277 & 95.52 \\
\hline \multicolumn{2}{|c|}{ Progressive onset } & 260 & 89.66 \\
\hline \multicolumn{2}{|c|}{ Ill general appearance } & 149 & 51.38 \\
\hline \multicolumn{2}{|c|}{ Fever } & 49 & 16.90 \\
\hline \multicolumn{2}{|c|}{ Joint damage } & 286 & 98.62 \\
\hline- & Large joints & 173 & 60.49 \\
\hline- & Mixed & 105 & 36.71 \\
\hline- & Small joints & 8 & 2.80 \\
\hline- & Bilateral and symmetrical & 180 & 74.69 \\
\hline- & Bilateral and asymetric & 61 & 25.31 \\
\hline \multicolumn{2}{|c|}{ Extra-articular involvement } & 106 & 52.83 \\
\hline \multicolumn{2}{|c|}{ Joints deformities } & 55 & 18.97 \\
\hline
\end{tabular}

Table 3. Distribution of patients according to extra-articular features.

\begin{tabular}{lcc}
\hline & Number $(\mathrm{n} / \mathrm{N})$ & Percentage $(\%)$ \\
\hline Dermato-mucosal & $56 / 106$ & 52.83 \\
Alopecia & $20 / 56$ & 35.71 \\
Erythema of the skin & $16 / 56$ & 28.57 \\
Oral ulceration & $9 / 56$ & 16.07 \\
Cutaneous sclerosis & $3 / 56$ & 5.36 \\
Rheumatoid nodules & $2 / 56$ & 3.57 \\
Skin achromia & $2 / 56$ & 3.57 \\
Psoriasis & $1 / 56$ & 1.78 \\
Malar Rash & $1 / 56$ & 1.78 \\
Eschar & $1 / 56$ & 1.78 \\
Raynaud & $1 / 56$ & 1.78 \\
Respiratory & $30 / 106$ & 28.30 \\
Dyspnea & $14 / 30$ & 46.67 \\
\hline
\end{tabular}




\begin{tabular}{|c|c|c|}
\hline Continued & & \\
\hline Cough & $12 / 30$ & 40.00 \\
\hline Chest pain & $4 / 30$ & 13.33 \\
\hline Ocular & $21 / 106$ & 19.81 \\
\hline Conjunctivitis & $19 / 21$ & 90.48 \\
\hline Glaucoma & $1 / 21$ & 4.76 \\
\hline Keratitis & $1 / 21$ & 4.76 \\
\hline Digestive & $19 / 106$ & 17.92 \\
\hline Dysphagia & $8 / 19$ & 42.10 \\
\hline Diarrhea & $6 / 19$ & 31.58 \\
\hline Odynophagia & $3 / 19$ & 15.79 \\
\hline Vomiting & $1 / 19$ & 5.26 \\
\hline Gastroesophageal reflux & $1 / 19$ & 5.26 \\
\hline Urogenital & $17 / 106$ & 16.04 \\
\hline Urethritis & $8 / 17$ & 47.06 \\
\hline Leukorrhea & $7 / 17$ & 41.18 \\
\hline Hematuria & $1 / 17$ & 5.88 \\
\hline Dysuria & $1 / 17$ & 5.88 \\
\hline Hematological & $5 / 106$ & 4.72 \\
\hline Adenopathy & $3 / 5$ & 60.00 \\
\hline Anemia & $2 / 5$ & 40.00 \\
\hline Myalgia & $1 / 106$ & 0.94 \\
\hline Sjogren's syndrome & $1 / 106$ & 0.94 \\
\hline
\end{tabular}

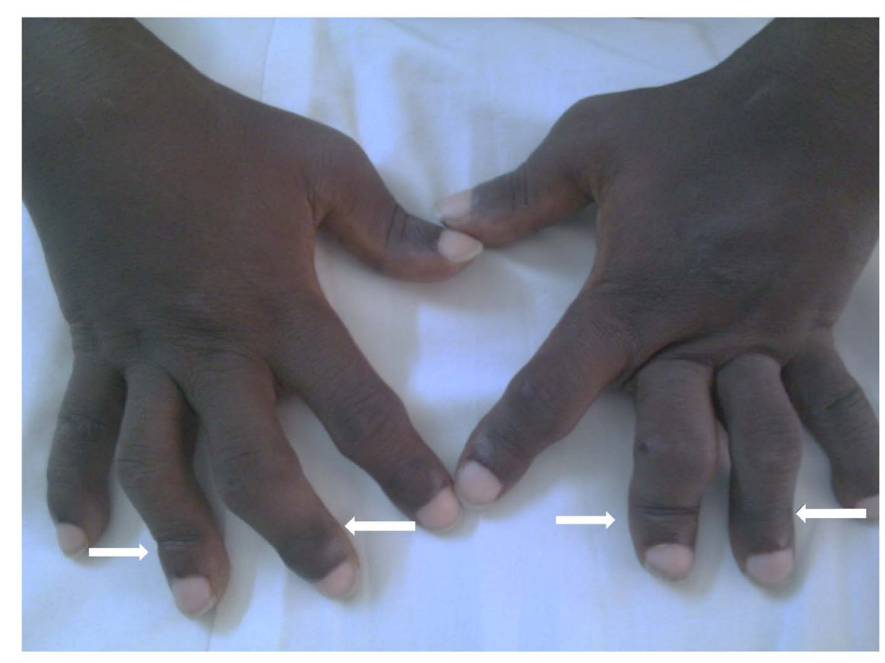

HAUT

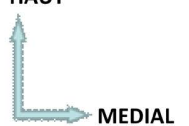

Figure 1. Buttonhole deformities of the $3 \mathrm{rd}$ and 4 th fingers in a patient suffering from rheumatoid arthritis (white arrows). 
in $58.33 \%$ of cases (Table 4). Carpitis (57.55\%) and osteoporosis (45.28\%) were the main radiographic lesions observed (Figure 2). Rheumatoid arthritis (41.03\%), undifferentiated chronic inflammatory rheumatic disease (UCIRD) (38.62\%), spondyloarthritis (SpA) (15.17\%) and systemic lupus erythematosus $(2.41 \%)$ were the common clinical forms. The average age at consultation of the 119 patients (41.03\%) with rheumatoid arthritis was $46.68 \pm 14.73$ and their average duration of evolution was $53.33 \pm 55.06$ months (Table 5). 289 patients

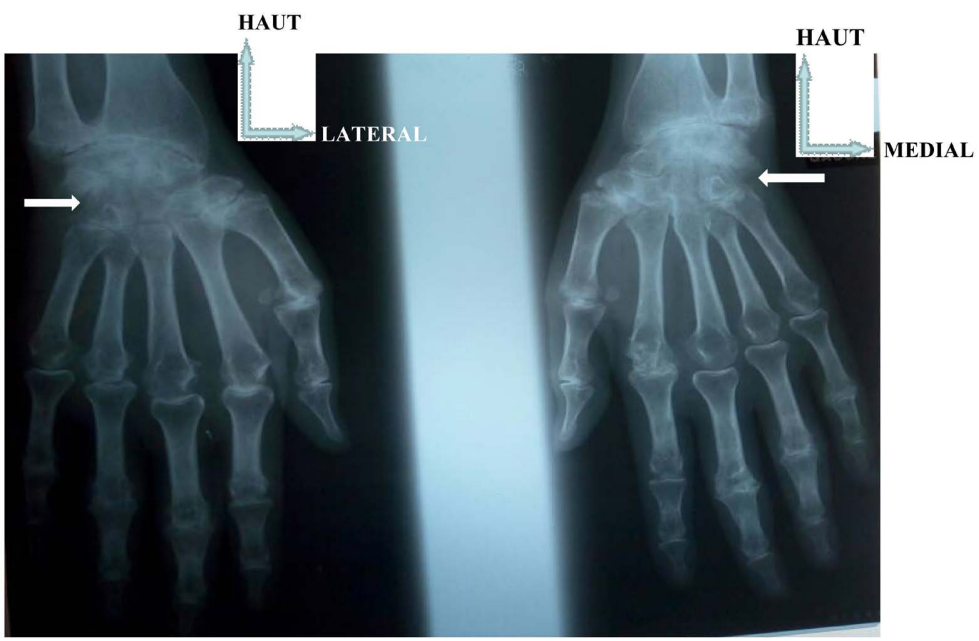

Figure 2. Frontal X-ray of the hands taking the wrists of a patient suffering from rheumatoid arthritis showing bilaterally a demineralization, erosions of the articular surfaces of the carpus bones, a global pinching of the radiocarpal space, a pinching of the spaces located between the various carpus bones leading to a fusion of the carpus bones realizing the image of fusing carpal tunnel (white arrows).

Table 4. Distribution of patients according to positivity of the immunological markers.

\begin{tabular}{ccccccc}
\hline & \multicolumn{2}{c}{ Positive } & \multicolumn{2}{c}{ Negative } & \multicolumn{2}{c}{ Totals } \\
\cline { 2 - 7 } & $\mathrm{N}$ & $\%$ & $\mathrm{~N}$ & $\%$ & $\mathrm{~N}$ & $\%$ \\
\hline Rheumatoid Factor & 17 & 54.84 & 14 & 45.16 & 31 & 77.50 \\
Anti-CCP* & 14 & 58.33 & 10 & 41.67 & 24 & 60.00 \\
ANAa & 3 & 33.33 & 6 & 66.67 & 9 & 22.50 \\
Anti-DNA natives & 3 & 42.86 & 4 & 57.14 & 7 & 17.50 \\
Anti-RNP** & 2 & 66.67 & 1 & 33.33 & 3 & 7.50 \\
Anti-Scl70*** & 2 & 66.67 & 1 & 33.33 & 3 & 7.50 \\
Anti-Sm ${ }^{* * *}$ & 2 & 66.67 & 1 & 33.33 & 3 & 7.50 \\
Anti-La & 1 & 50.00 & 1 & 50.00 & 2 & 5.00 \\
Anti-Ro & 1 & 50.00 & 1 & 50.00 & 2 & 5.00 \\
Anti-Jo1 & 0 & 0.00 & 1 & 100.00 & 1 & 2.50 \\
\hline
\end{tabular}

${ }^{\star}$ Anti-citrullinated cyclic peptides; ${ }^{\star \star}$ Anti-Ribonucleoprotein; ${ }^{\star * \star}$ Anti-topoisomerase I;

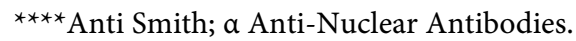


Table 5. Distribution of patients according to their diagnosis.

\begin{tabular}{ccccc}
\hline & Number (\%) & $\begin{array}{c}\text { Sex ratio } \\
(\mathrm{M} / \mathrm{F})\end{array}$ & $\begin{array}{c}\mathrm{MAP}^{\alpha} \pm \mathrm{SD}^{*} \\
\text { (years) }\end{array}$ & $\begin{array}{c}\mathrm{MTP}^{\infty} \pm \mathrm{SD}^{*} \\
\text { (months) }\end{array}$ \\
\hline Rheumatoid arthritis & $119(41.03)$ & $8 / 111$ & $46.68 \pm 14.73$ & $53.33 \pm 55.06$ \\
UCIRD & $11 *(38.62)$ & $30 / 82$ & $41.81 \pm 15.66$ & $30.27 \pm 46.05$ \\
Reactive arthritis & $23(7.93)$ & $9 / 14$ & $40.52 \pm 12.69$ & $10.86 \pm 13.61$ \\
Ankylosing spondylitis & $20(6.90)$ & $15 / 5$ & $34.65 \pm 14.64$ & $62.5 \pm 85.74$ \\
SLE & $7(2.41)$ & $1 / 6$ & $32.71 \pm 8.51$ & $36.71 \pm 36.02$ \\
Systemic scleroderma & $4(1.38)$ & $0 / 4$ & $34.24 \pm 13.15$ & $15.75 \pm 14.15$ \\
Adult Still's disease & $2(0.69)$ & $1 / 1$ & 28 & 116 \\
Polymyositis & $2(0.69)$ & $0 / 2$ & 34 & 19 \\
Psoriasis arthritis & $1(0.34)$ & $0 / 1$ & 56 & 12 \\
\hline
\end{tabular}

${ }^{\star}$ Standard deviation; ${ }^{* *}$ Systemic lupus erythematosus; ${ }^{* *}$ Undifferentiated Chronic Inflammatory rheumatic diseases; ${ }^{\alpha}$ Mean age at presentation; ${ }^{\infty}$ Mean time of progression.

(99.66\%) received symptomatic treatments namely NSAIDs (73.36\%) and corticosteroids (51.90\%), and 90 patients (31.03\%) received synthetic DMRDs, mostly methotrexate (88.89\%). The mean follow-up time was $13.36 \pm 13.12$ months (extremes: 1 and 42 months). One hundred and seventy-one patients (58.97\%) were lost to follow-up. The evolution was favorable in 81 patients $(27.93 \%)$ and unfavorable in 37 patients (12.76\%). The only case of death $(0.34 \%)$ recorded in our series occurred as a result of septic shock.

\section{Discussion}

We observed 290 cases of CIRD among the 20333 patients examined in nine years. Rheumatoid arthritis (RA), UCIRD, SpA and systemic lupus erythematosus (SLE) were the commonest CIRDs observed in Lome. Rigorous interpretation of these results requires taking into account the shortcomings related to selection bias and limited technical platform. This was a hospital-based study which only took into account patients examined in rheumatology units, thus constituting a bias which makes it impossible to generalize our results. The limited technical platform (absence of an immunology laboratory) did not allow us to specify the nature of some inflammatory rheumatic diseases. On the other hand, not all rheumatic patients consult the health centers because of the frequent recourse to traditional healers. However, the shortcomings of our study do not affect its epidemiological importance. In our study, incidence of CIRD in hospital setting was $1.43 \%$. This rarity of CIRD in our context can be explained by several reasons: inaccessibility to health facilities, the clinical polymorphism of these pathologies and the lack of medical specialists. The demographic, clinical, laboratory and radiological features in our sample are similar to other African studies [19] [20] [21] [22]. RA is the most frequent CIRD in our sample. Its peculiarity 
is the predominance of erosive deforming forms with a higher activity of the disease, mostly due to delays in diagnosis [9]. It represents $41.03 \%$ of all CIRDs, ahead of UCIRD and SpA. Similar results have been reported in other Western and Central African countries [21] [23]. This result contrasts with other African studies where SpA was at the first [19] [22] or second [24] [25] position after UCIRD. This high frequency of UCIRD is due to the limited technical platform on the one hand, and on the other hand to the low income level of the population whose financial means do not allow them to afford immunological tests, at often very high costs. In Congo-Brazzaville, the establishment of a specialized immunological medical laboratory has made it possible to perform immunological tests on all the 90 patients [26]. In contrast to Caucasian SpA, which are dominated by ankylosing spondylitis, reactive arthritis is the primary entity of this group in sub-Saharan Africa due to the high frequency of endemic infectious diseases in tropical areas and the poor community and individual hygiene measures [22]. The rarity of the HLA-B27 gene susceptibility is commonly recognized in black people, regardless of continent [27]. Although a relation between HIV infection and reactive arthritis or psoriatic arthritis is sometimes observed, its low frequency does not allow HIV infection to be considered as risk factor for SpA in Africa [28].

The other connective tissue diseases (systemic lupus erythematosus, systemic scleroderma, Still's disease, polymyositis) are relatively rare in sub-Saharan Africa [8] [10] [29] [30] [31]. The frequent prescription of methotrexate could be explained on the one hand by the affordable cost and the availability of the drug in our areas and on the other hand by the high frequency of RA, methotrexate being the first-line background treatment in the management of RA according to the 2018 recommendations of the French Society of Rheumatology [32]. No patient has been treated with biotherapy, although the efficacy of biological DMARDs has been demonstrated in developed and developing countries [33]. Difficulties in its access, high cost and major side effects including high risk of infection could explain this.

\section{Conclusion}

Chronic inflammatory rheumatic diseases are common diseases in rheumatological practice in Togo and deserve special attention. The establishment of a specialized immunology laboratory would be very useful for diagnosis and for early management of these diseases.

\section{Conflicts of Interest}

The authors declare no conflicts of interest regarding the publication of this paper.

\section{References}

[1] Scott, D.L., Wolfe, F. and Huizinga, T.W. (2010) Rheumatoid Arthritis. The Lancet, 
376, 1094-1108. https://doi.org/10.1016/S0140-6736(10)60826-4

[2] Rat, A.-C. (2014) Epidemiology of Spondyloarthritis in the 21st Century. Revue du Rhumatisme Monographies, 81, 225-229.

[3] Lèye, Y., Ndiaye, N., Diack, N., Ndour, M., Fall, B., Kâ, W., et al. (2017) Epidemiological and Diagnostic Aspects of Connectivites in the Internal Medicine Department of CHUN of Pikine: Analysis of 287 Observations. Revue Africaine de Medecine Interne, 4, 22-25.

[4] Singwe-Ngandeu, M., Meli, J., Ntsiba, H., Nouédoui, C., Yollo, A., Sida, M., et al. (2007) Rheumatic Diseases in Patients Attending a Clinic at a Referral Hospital in Yaunde, Cameroon. East African Medical Journal, 84, 404-409. https://doi.org/10.4314/eamj.v84i9.9549

[5] Ouédraogo, D.-D., Korsaga-Some, N., Zabsonné, T.J., Tiéno, H., Kaboré, H., Niamba, P., et al. (2014) Connective Tissue Diseases in Hospital Practice in Ouagadougou (Burkina Faso). Médecine et Santé Tropicales, 24, 271-274. https://doi.org/10.4314/eamj.v84i9.9549

[6] Missounga, L., Ouedraogo, D.D., Nseng Nseng, I.R., Singwe-Ngandeu, M., Daboiko, J.C., Eti, E., et al. (2018) Rheumatology in French-Speaking Sub-Saharan Africa Countries and Madagascar: Rheumatologists, Main Rheumatic Diseases, Diagnostic and Therapeutic Resources in 2015. Medecine d Afrique Noire, 65, 59-68.

[7] Mijiyawa, M., Amanga, K., Oniankitan, O., Pitché, P. and Tchangaï-Walla, K. (1999) Connective Tissue Diseases in Hospital Consultations in Lomé (Togo). Revue de Médecine Interne, 20, 13-17. https://doi.org/10.1016/S0248-8663(99)83004-5

[8] Kombate, K., Saka, B., Oniankitan, O., Sodonougbo, P. and Pitche, P. (2008) Systemic Lupus in Lomé, Togo. Medecine Tropicale, 68, 283-286.

[9] Kakpovi, K., Houzou, P. and Fianyo, E. (2017) Profile of Rheumatoid Arthritis in Rheumatological Consultation in Lomé (Togo). European Scientific Journal, 13, 125 132. https://doi.org/10.19044/esj.2017.v13n24p267

[10] Akakpo, A., Teclessou, J., Mouhari-Touré, A., Saka, B., Matakloe, H., Kakpovi, K., et al. (2017) Scleroderma in Hospital Settings in Lomé: A Study of 50 Cases. Tropical Medicine and Health, 24, 446-448. https://doi.org/10.1684/mst.2017.0701

[11] Teclessou, J., Saka, B., Akakpo, A., Matakloe, H., Mouhari-Touré, A., Kombate, K., et al. (2018) Connectivitis in the Hospital Setting in Lomé: A Retrospective Study of 231 Cases. Pan African Medical Journal, 30, 1-7. https://doi.org/10.11604/pamj.2018.30.176.14565

[12] Hua, C. and Combe, B. (2017) The New ACR/EULAR 2010 Classification Criteria for Earlier Diagnosis of Rheumatoid Arthritis. Revue du Rhumatisme Monographies, 84, 337-342. https://doi.org/10.1016/j.monrhu.2017.07.001

[13] Lekpa, F.K. and Claudepierre, P. (2009) Spondyloarthritis, from Diagnosis to Nosology: Criteria and Limitations. Revue Du Praticien, 59, 519-532.

[14] Meyer, O. (2010) Lupus et Syndrome des Anticorps Antiphospholipides. Critères de Diagnostic et de suivi Systemic Lupus Erythematosus and Antiphospholipid Syndrome. Diagnostic and Follow-Up Criteria. Revue Du Rhumatisme Monographies, 77, 82-88. https://doi.org/10.1016/j.monrhu.2010.02.006

[15] Elhai, M., Avouac, J., Kahan, A. and Allanore, Y. (2015) Systemic Scleroderma: Recent Progress. Revue du Rhumatisme, 4469, 1-7. https://doi.org/10.1016/S1286-935X(15)72882-0

[16] Guis, S., Mattei, J., Figarella-branger, D. and Bendahan, D. (2010) Idiopathic Inflammatory Myopathies of the Adult: Diagnostic and Classification Criteria. Revue Du Rhumatisme Monographies, 77, 99-102. 
https://doi.org/10.1016/j.monrhu.2010.01.011

[17] Mitrovic, S. and Fautrel, B. (2018) Still or Pseudo-Still: Difficulties and Pitfalls in the Diagnosis of Adult Still's Disease. Revue Du Rhumatisme Monographies, 468, 1-8.

[18] Lioté, F. (2010) Psoriatic Rheumatism: Criteria for Classification, Diagnosis and Therapeutic Response. Revue du Rhumatisme Monographies, 77, 67-73. https://doi.org/10.1016/j.monrhu.2009.12.004

[19] Mijiyawa, M., Etey, K. and Amedegnato, M.D. (1993) Chronic Inflammatory Rheumatism in Hospital Consultation in Lomé (Togo). Rheumatology, 45, 45-49.

[20] Oniankitan, O., Houzou, P., Tagbor, K.C., Fianyo, E., Koffi-Tessio, V.E.S., Kakpovi, K., et al. (2013) Etiology of Arthritis in Lomé (Togo). Open Journal of Rheumatology and Autoimmune Diseases, 3, 154-158.

https://doi.org/10.4236/ojra.2013.33023

[21] Missounga, L., Nziengui Madjinou, M.I.C., Mwenpindi Malekou, D., Nseng Nseng, I.R., Mouendo Mouloungui, E.G. and Efemba, C.D. (2020) Focus on the Prevalence and Costs of Inflammatory Rheumatism in Gabon. La Lettre du Rhumatologue, 464, 14-17.

[22] Daboiko, J.-C., Ouattara, B., Ouali, B., Missounga, L., Berté, M.-J., Eti, E., et al. (2003) Reactive Arthritis in Ivorian Hospitals: Epidemiologic, Clinical and Radiologic Aspects. Afrique Biomédicale, 8, 17-20.

[23] Ouédraogo, D.D., Ntsiba, H., Tiendrébéogo-Zabsonré, J., Tiéno, H., Bokossa, L.I.F., Kaboré, F., et al. (2014) Clinical Spectrum of Rheumatologic Diseases in a Department of Rheumatology in Ouagadougou (Burkina Faso). Clinical Rheumatology, 33, $385-$ 389. https://doi.org/10.1007/s10067-013-2455-4

[24] Houzou, P., Oniankitan, O., Kakpovi, K., Koffi-tessio, V.E.S., Tagbor, K.C., Fianyo, E., et al. (2013) Profile of Rheumatic Conditions in 13517 West African Patients. Tunisie Medicale, 91, 16-20.

[25] Kakpovi, K., Koffi-Tessio, V., Houzou, P., Fianyo, E., Tagbor, K.C., Oniankitan, O., et al. (2016) Rheumatologic Conditions Observed in Hospitalization in Lome (Togo). Journal de Recherche Scientifique Universite de Lomé, 18, 361-370.

[26] Lamini N'Soundhat, N.E. and Ntsiba, H. (2020) Auto Immune and System Diseases in the Rheumatology Department of the University Hospital of Brazzaville. Health Sciences and Diseases, 21, 138-142.

[27] Reveille, J.D., et al. (2019) HLA Class I and II Alleles in Susceptibility to Ankylosing Spondylitis. Annals of the Rheumatic Diseases, 78, 66-73. https://doi.org/10.1136/annrheumdis-2018-213779

[28] Tikly, M., et al. (2014) Spondyloarthritis in Sub-Saharan Africa. Current Rheumatology Reports, 16, 421. https://doi.org/10.1007/s11926-014-0421-Z

[29] Zomalheto, Z., Assogba, M., Agbodande, A., Atadokpede, F., Gounongbe, M. and Avimadje, M. (2014) Systemic Lupus Erythematosus: Particularities in Benin and West Africa. Tunisie Médicale, 92, 707-710.

[30] Diallo, S., Niasse, M. and Diouf, C. (2014) Still's Disease in Children and Adults. Etude de 16 observations. Revue Cames Sante, 2, 29-34.

[31] Diallo, M., Fall, A., Diallo, I., Diédhiou, I., Ba, P., Diagne, M., et al. (2010) Dermatomyositis and Polymyositis: 21 Cases in Senegal. Médecine Tropicale, 70, 166-168.

[32] Daien, C., Hua, C., Gaujoux-Viala, C., Cantagrel, A., Dubremetz, M., Dougados, M., et al. (2019) Update of the French Society of Rheumatology Recommendations for the Management of Rheumatoid Arthritis. Revue Du Rhumatisme, 86, 8-24. https://doi.org/10.1016/j.rhum.2018.09.008 
[33] Missounga, L., Iba Ba, J., Nseng Nseng Ondo, R.I., Nziengui Madjinou, M.I., Mwenpindi Malekou, D., Mouendou Mouloungui, E.G., et al. (2018) Treatment of Chronic Inflammatory Rheumatism with Biotherapies in Gabon: Eligibility and Follow-Up of the First 8 Patients in Sub-Saharan Africa. Tropical Medicine and Health, 28, 197-200. https://doi.org/10.1684/mst.2018.0781 